if he knew that the loss would fall on him if it occurred. This is fairly typical of the commercial lease and the risk of fire destroying or damaging the premises. Here nothing would be gained by striking down an exculpatory clause because the negligence of the exculpated party caused the loss, and a good deal would be lost if both parties were obliged to insure because of doubt as to whether or not the law would void the exculpatory term.

The most difficult situation arises where one of the two parties would not as a general rule either have insurance or insure if he knew that he was to bear any resulting losses. This is typical of parcel checkrooms and similar service bailments. Perhaps the mere fact that no one will insure unless the bailee is compelled to is sufficient justification for voiding exculpatory efforts in these situations. Apparently courts think so; at least that is the end result of the "token" doctrine. It would be far better if the policy decision were made explicit.

out of line with the risk of towing barges on relatively calm rivers. Presumably this will in time be adjusted so that the end result will be but little more expensive than the old method. It will be interesting to see whether the cost of insurance to the tow will go down because of the possibility of recovery over against the tug.

This illustrates one important aspect of exculpatory law. The effect of surprise due to a change in the law is often more expensive than leaving things as they were. Courts should, in this area, be very hesitant to reverse an established practice such as existed before the Bisso decision.

\title{
USE OF EXTRA-RECORD INFORMATION IN CUSTODY CASES
}

Litigation resulting from broken homes continually presents courts with the problem of determining, on the basis of the economic, sociological and psychological factors involved in a family relationship, the custody arrangement which will best promote the child's welfare. ${ }^{1}$ Feeling the need for expert advice and distrusting the evidence usually adduced in such proceedings, ${ }^{2}$ many judges consult undisclosed reports of social workers' investigations ${ }^{3}$ into the family situation, which frequently contain information supplied by others as well as the investigator's personal observations. Furthermore, to ascertain the child's feelings many judges interview him in chambers, without the presence of parties

1 Most custody cases state that the sole issue is the child's welfare. Consult Sayre, Awarding Custody of Children, 9 U. of Chi. L. Rev. 672, 676-85 (1942).

2 Consult Alexander, Let's Get the Embattled Spouses out of the Trenches, 18 Law and Contemp. Prob. 98, 99-100 (1953).

${ }^{3}$ Courts recognize social workers as experts in family relations. See, e.g., Fewel v. Fewel, 23 Cal.2d 431, 435, 144 P.2d 592, 594-95 (1943). Several courts feel their help so valuable that custody awards based on conflicting testimony have been remanded for advice of a social worker. Gluckstern v. Gluckstern, 2 App.Div.2d 744, 153 N.Y.S.2d 184 (1956); Withrow v. Withrow, 212 La. 427, 31 So.2d 849 (1947); Boone v. Boone, 150 F.2d 153 (App. D.C., 1945). In West v. West, 208 S.C. 1, 36 S.E.2d 856 (1946), a social worker's report was obtained by the appellate court and relied on in reversing the trial court. 
or counsel. ${ }^{4}$ Despite the concededly valuable information furnished by these practices, they would appear difficult to reconcile with the due process objection to "secret evidence." Yet both legal and practical considerations may thwart attempts to meet this objection through disclosure of the reports and interviews to the parties. ${ }^{5}$

Before discussion of these questions, it must be noted that most custody cases involving the use of reports or interviews are affirmed on appeal by application of one of two rules, both of which avoid any decision on the legality of the procedure followed. First, it is generally held that the parties' express consent $t^{6}$ avoids any error in extra-record consultation or admission in evidence of reports ${ }^{7}$ or interviews. ${ }^{8}$ Only one case has been found rejecting this rule. Thus, in Cohn v. Scott ${ }^{9}$ the parties' consent to an ex parte investigation by the judge was held not to waive error, on the ground that "agreement of counsel cannot bind as to the interests of the minor, which is the paramount question in these proceedings."10 Insofar as this case indicates that the parties' loss of

1 On the frequency of judicial use of social workers' reports and interviews with the child in custody cases, consult Rea v. Rea, 195 Ore. 252, 258, 245 P.2d 884, 886 (1952); Cochran, Children of Divorce, 11 Ky. S. B. J. 201, 207 (1947).

$s$ This comment will be confined to custody litigation between parents or relatives arising from a divorce or separation. For statistics consult Gellhorn, Children and Families in the Courts of New York City 319-20 (1954) and Squire, Divorce and the Friend of the Court, 29 Mich. S. B. J. 15, 19 (April, 1950). Analogous problems arise in proceedings under adoption and juvenile court statutes to deprive parents of the custody of delinquent or dependent and neglected children. Consult, e.g., Attkisson v. Usrey, 224 Ind. 155, 65 N.E.2d 489 (1946); State ex rel. Palagi v. Freeman, 81 Mont. 132, 262 Pac. 168 (1927).

- Failure to make timely objection to the admission in evidence of an account of a private interview with the child is treated in accordance with the general rule that such failure waives any error. Brugel v. Hildebrandt, 332 Mich. 475, 52 N.W.2d 190 (1952). Failure to make timely objection to admission in evidence of social workers' reports likewise waives any error. Cooksey v. Perkins, 263 S.W.2d 952 (Tex. Civ. App., 1954); Wirth v. Wirth, 192 Md. 21, 63 A.2d 312 (1949). But express consent is usually required to waive the more vital rights involved in consideration by the trial court of reports or interviews never placed on record. Thompson v. Thompson, 238 Minn. 41, 55 N.W.2d 328 (1952); Commonwealth ex rel. Balick v. Balick, 172 Pa.Super. 196, 92 A.2d 703 (1952); Holland v. Holland, 75 N.E.2d 489 (Ohio App., 1947); Moon v. Moon, 62 Cal.App.2d 185, 144 P.2d 596 (1944); Test v. Test, 131 N.J.Eq. 197, 24 A.2d 226 (1942). Contra: Lorang v. Lorang, 42 Wash.2d 539, 256 P.2d 481 (1953); Martinez v. Martinez, 49 N.M. 405, 165 P.2d 125 (1946).

${ }^{7}$ Report admitted in evidence: Baranet v. Baranet, 206 Ore. 316, 292 P.2d 793 (1956); De Boynton v. De Boynton, 137 Cal.App.2d 106, 289 P.2d 868 (1955); Justice v. Hobbs, 245 Iowa 707, 63 N.W.2d 882 (1954); Newman v. Newman, 104 N.E.2d 707 (Ohio App., 1951). Report considered privately but not admitted in evidence: Rea v. Rea, 195 Ore. 252, 245 P.2d. 884 (1952); Crawford v. Crawford, 256 S.W.2d 875 (Tex. Civ. App., 1952); Jones v. Jones, 23 Wash.2d 657, 161 P.2d 890 (1945).

${ }^{8}$ Interview reported in court: Gantner v. Gantner, 39 Cal.2d 272, 246 P.2d 923 (1952); Kelly v. Applewhite, 231 S.W.2d 974 (Tex. Civ. App., 1950); Penn v. Abell, 173 S.W.2d 483 (Tex. Civ. App., 1943). Interview kept secret: Sturm v. Sturm, 138 Cal.App.2d 25, 291 P.2d 527 (1956); Habich v. Habich, 44 Wash.2d 195, 266 P.2d 346 (1954).

9231 Ill. 556, 83 N.E. 191 (1907), aff'g 134 Ill.App. 195 (1907).

${ }_{10}$ Ibid., at 559 and 192; see Watkins v. Watkins, 221 Ind. 293, 296-97, 47 N.E.2d 406, 407 (1943). Consult note 1 supra. 
standing to complain should not preclude consideration of the child's interests, it seems unobjectionable. However, the assumption that the procedure followed was in fact detrimental to the child is open to critical examination. If incorrect, a result similar to that of the general rule on express consent should be reached.11

The second rule is that sufficient legal evidence in support of the findings renders non-prejudicial any error in admission of evidence ${ }^{12}$ or consideration of secret material. ${ }^{13}$ Although several courts in both situations have disregarded this rule and reversed without any discussion of the other evidence, ${ }^{14}$ the rule has been explicitly rejected by only two cases. One of these cases declared that consideration by the trial judge of a secret report "contravenes the American Ideal of due process of law, ${ }^{\prime 15}$ and the other reversed on the ground that such consideration precludes the required de novo appellate review. ${ }^{16}$

11 The requirement of the parties' consent may be a small obstacle for a court wishing to use reports and private interviews; when the judge indicates a desire to use these materials and asks for the parties' consent, counsel may often give it to avoid prejudicing their case. Consult, e.g., Withrow v. Withrow, 212 La. 427, 31 So.2d 849 (1947) (Trial judge stated that under the evidence neither spouse should get custody and requested consent to an independent investigation. On plaintiff's refusing consent, custody was awarded to defendant.).

12 Reports admitted in evidence: Nance v. Nance, - Ark. - , 292 S.W.2d 74 (1956); Austad v. Austad, 2 Utah 2d 49, 60, 269 P.2d 284, 291-92 (1954); Liner v. Liner, 222 La. 789, 64 So.2d 4 (1953); Brugel v. Hildebrandt, 332 Mich. 475, 52 N.W.2d 190 (1952); Biles v. Biles, 107 Cal.App.2d 200, 236 P.2d 621 (1951). Interview reported in court: Brugel v. Hildebrandt, 332 Mich. 475,52 N.W.2d 190 (1952).

The usual justification for affirming findings despite admission below of incompetent evidence is a presumption that the judge disregarded such evidence. Incompetent Evidence in Nonjury Trials: Ought We Presume That It Has No Effect? 29 Ind. L. J. 446 (1954). But most of the cases cited in this footnote and in note 13 infra do not mention this presumption, for, although it may plausibly be raised when the incompetent evidence is given by a party's witness, one can hardly presume that the judge himself instigated an investigation or interview for the purpose of disregarding relevant information there obtained.

A parallel rule is that error in the trial judge's consideration of reports or interviews is nonprejudicial where the judge states that he did not give any weight to these sources. Jenkins v. Jenkins, 125 Cal.App.2d 109, 269 P.2d 908 (1954); Rowell v. Rowell, 211 Ga. 127, 84 S.E.2d 23 (1954). Under this rule the findings could hardly be affirmed without sufficient legal evidence on record. However, even with such evidence the findings could be reversed if it appeared that the trial judge gave weight to the report or interview.

18 Reports not placed on record: Lorang v. Lorang, 42 Wash.2d 539, 256 P.2d 481 (1954). Contra: Williams v. Williams, 8 Ill. App.2d 1, 130 N.E.2d 291 (1955); Commonwealth ex rel. Mark v. Mark, 115 Pa.Super. 181, 175 Atl. 289 (1934). Interviews not placed on record: Peeples v. Newman, 209 Ga. 53, 57, 70 S.E.2d 749, 753 (1952); Brugel v. Hildebrandt, 332 Mich. 475, 52 N.W.2d 190 (1952).

14 E.g., In re Gupton, 238 N.C. 303, 77 S.E.2d 716 (1953); Tumbleson v. Tumbleson, 117 Ind.App. 455, 73 N.E.2d 59 (1947); Wunsch v. Wunsch, 248 Wis. 29, 20 N.W.2d 545 (1945).

15 Williams v. Williams, 8 Ill.App.2d 1, 130 N.E.2d 291 (1955), noted in 44 Ill. B. J. 571 (1956). On the applicability of due process to custody proceedings, consult 353 infra.

16 Commonwealth ex rel. Mark v. Mark, 115 Pa.Super. 181, 175 Atl. 289 (1934).

The scope of appellate review in custody cases may depend on the form of proceeding. Child custody awards generally are considered equitable decrees, 4 Pomeroy, Equity Jurisprudence 874-75 (5th ed., Symons, 1941), for which a de novo review of the record is customary. McClintock, Equity 40 (1948). But custody awards are sometimes given in habeas corpus proceedings, an action at law for which the scope of review is limited to the existence of sub- 
Where the propriety of using social workers' reports or interviews with the child must be squarely faced, three questions arise: the legality of considering such material without disclosure of its contents to the parties, the adequacy of alternative procedures and their availability under existing rules of evidence.

Judicial consideration of social workers' reports which have not been admitted in evidence or otherwise disclosed to the parties is universally held erroneous, ${ }^{17}$ reflecting the general rule that on factual questions not subject to judicial notice a tribunal may not consider material which is unknown to the parties. ${ }^{18}$ However, at least one statute seems to authorize consultation of such secret reports, ${ }^{19}$ without the requirement found in some statutes that the report be made available to the parties ${ }^{20}$ or that the investigator be subject to cross-examination, ${ }^{21}$ or both. ${ }^{22}$

stantial evidence to support the findings. 2 Spelling, Extraordinary Remedies 1159-60, 116465 (2d ed., 1901).

Only four states have been found in which the scope of review does turn on the form of proceeding. In Arkansas, Michigan, and Tennessee habeas corpus proceedings involving child custody are reviewed as actions at law. Massey v. Flinn, 198 Ark. 279, 128 S.W.2d 1008 (1939); Carpenter v. Carpenter, 149 Mich. 138, 112 N.W. 748 (1907); Cecil v. State ex rel. Cecil, 192 Tenn. 74, 237 S.W. 2 d 558 (1951). Custody awards in divorce proceedings, however, are reviewed de novo. Johnston v. Johnston, - Ark. -, 283 S.W.2d 151 (1955); Rusco v. Rusco, 331 Mich. 600, 50 N.W.2d 169 (1951); Smith v. Smith, 188 Tenn. 430, 220 S.W.2d 627 (1949). An unusual situation exists in Minnesota, where habeas corpus proceedings involving child custody are reviewable de novo, under Minn. Stat. (1953) c. 589, $\$ 30$, while custody awards in divorce proceedings are reviewed as judgments at law. Stoll v. Stoll, $243 \mathrm{Minn} .510$, 68 N.W.2d 367 (1955).

In practice the difference between the scope of review of custody awards in law and equity may be negligible. Courts purporting to review de novo often indulge a presumption in favor of the findings below, e.g., Shepard v. Gerholdt, 244 Iowa 1343, 60 N.W.2d 547 (1953), while courts using the law scope of review often find an "abuse of discretion" and reverse when in disagreement with the trial judge on the weight of the evidence. Bunim v. Bunim, 298 N.Y. 391, 83 N.E.2d 848 (1949). Consult Clark and Stone, Review of Findings of Fact, 4 U. of Chi. L. Rev. 190, 207-11, 215 (1937).

${ }^{17}$ Representative cases are: Fewel v. Fewel, 23 Cal.2d 431, 144 P.2d 592 (1943); Williams v. Williams, 8 Ill.App.2d 1, 130 N.E.2d 291 (1955); Tumbleson v. Tumbleson, 117 Ind. App. 455, 73 N.E.2d 59 (1947); Thompson v. Thompson, 238 Minn. 41, 55 N.W.2d 329 (1952); Test v. Test, 131 N.J.Eq. 197, 24 A.2d 226 (1942); In re Gupton, 238 N.C. 303, 77 S.E.2d 716 (1953); Nelson v. Nelson, 180 Ore. 275, 176 P.2d 648 (1947); Holland v. Holland, 75 N.E.2d 489 (Ohio App., 1947); Commonwealth ex rel. Mark v. Mark, 115 Pa.Super. 181, 175 Atl. 289 (1934); Wunsch v. Wunsch, 248 Wis. 29, 20 N.W.2d 545 (1945).

Most of the cases rely on statements by the judge indicating that he considered the offrecord report. E.g., Wunsch v. Wunsch, 248 Wis. 29, 20 N.W.2d 545 (1945). Without such a statement there seems no way that appellant can show commission of the error (unless a statute requires submission of the report). Consult Watkins v. Watkins, 221 Ind. 293, 47 N.E.2d 606 (1943); Cline v. May, 287 S.W.2d 226 (Tex. Civ. App., 1956).

${ }^{18}$ The leading case is Interstate Commerce Commission v. Louisville and Nashville R.R. Co., 227 U.S. 88 (1913).

${ }^{19}$ Va. Code Ann. (Supp., 1956) tit. 16.1, \$\$158(1)(e), 208(1), 209.

${ }^{20}$ Mass. Laws Ann. (1955) c. 215, §56A; Neb. Rev. Stat. (1952) c. 42, §307; Ohio Rev. Code (Baldwin, 1956) c. 3105 , $\$ 8$.

21 Cal. Code Civ. Proc. (Deering, 1953) \$263.

22 Maine Rev. Stat. (1954) c. 166, \$69; N.J. Rules of Court (1953) Rule 4:98-8(d), implementing N.J. Rev. Stat. (1952) tit. 2A, c. 168, $\$ 13$. 
In many custody cases, the rule against "secret evidence" is said to be based on due process or similar constitutional provisions, ${ }^{23}$ although there is no discussion of why interests in custody are deemed to fall within the language of these provisions. Such explanation as is available may be found in cases holding due process guarantees applicable to custody interests in other procedural situations. One leading case ${ }^{24}$ relies on Supreme Court decisions holding that statutes unreasonably regulating children's education infringe the "liberty" of schoolteachers and parents. Other cases classify custody interests as "property" rights. ${ }^{25} \mathrm{~A}$ final approach is that due process protects every litigant "in any matter affecting his or her interest." ${ }^{\prime 26}$

A concession that custody interests are covered by constitutional guarantees does not, however, require the conclusion that in custody cases consideration of secret reports is unconstitutional. In Williams v. New York ${ }^{27}$ the Supreme Court, while adhering to its prior holding that the sentencing procedure in a criminal case is subject to due process limitations, ${ }^{28}$ upheld a death sentence based on information not made available to counsel on the ground that "open court testimony with cross-examination"-required when the issue is "guilt of a particular offense"-would be "totally impractical if not impossible" in the determination of an appropriate sentence, for which the judge should have the "fullest information possible concerning the defendant's life and characteristics." ${ }^{29}$ This reasoning has been applied to permit consideration of secret re-

${ }^{23}$ E.g., Williams v. Williams, 8 Ill.App.2d 1, 130 N.E.2d 291 (1955); Test v. Test, 131 N.J.Eq. 197, 24 A.2d 226 (1942); see People ex rel. Bernat v. Bicek, 405 Ill. 510, 526, 91 N.E.2d 588,596 (1950).

24 Sinquefield v. Valentine, 159 Miss. 144, 132 So. 81 (1931) (notice and opportunity to be heard).

${ }^{25}$ Brooks v. De Witt, 178 S.W.2d 718, 723 (Tex. Civ. App., 1944), rev'd on other grounds 143 Tex. 122, 182 S.W.2d 687 (1944); Kennedy v. Meara, 127 Ga. 68, 78, 56 S.E. 243, 247-48 (1906).

This view is not without difficulty. It may be suggested that constitutional protection arises from a property right in the child's services. See Schiltz v. Roenitz, 86 Wis. 31, 56 N.W. 194 (1893). However, the parents' right to services is commonly stated to be correlative with the duty to support rather than with the right to custody. Keller v. St. Louis, 152 Mo. 596, 54 S.W. 438 (1899); see Houston Oxygen Co. v. Davis, 139 Tex. 1, 161 S.W.2d 474 (1942); cf. Smith v. Hewett, 235 N.C. 615, 70 S.E.2d 825 (1952); consult Peck, Domestic Relations 374 (3d ed., 1930). Basing constitutional protection on this "property" right thus leads to the paradoxical conclusion that due process does not apply to deprivation of custody as long as the deprived parent retains the duty to support. Perhaps a more realistic approach would point out that companionship of one's child is a legally recognized interest. Prosser, Torts 692-93 (2d ed., 1955). But since an action for loss of companionship can generally be maintained only by a parent with the right to services, ibid., one may argue that loss of companionship is merely an element of damages, not in itself giving rise to a cause of action and therefore not a "property" right.

${ }^{26}$ Harloe v. Harloe 129 W.Va. 1, 5, 38 S.E.2d 362, 364 (1946) (notice and opportunity to be heard).

27337 U.S. 241 (1949).

${ }^{28}$ Townsend v. Burke, 334 U.S. 736 (1948) (denial of due process where defendant at a sentencing hearing had not been advised of his right to counsel and the judge in fixing sentence had relied on misinformation).

29 Williams v. New York, 337 U.S. 241, 247, 250 (1949). 
ports and hearsay in proceedings to determine the disposition of juveniles already found delinquent or dependent and neglected..$^{30}$ In these proceedings, where the paramount question is the child's welfare, ${ }^{31}$ consideration of the "whole life and characteristics" of the parents and child would seem required. Thus, custody litigation within the family, which involves a similar inquiry, would also appear to call for the Williams result.

In the last analysis, however, it is probable that in custody cases the rule against "secret evidence" will continue to be followed and the Williams reasoning rejected. ${ }^{32}$ The essential unfairness in extra-record consideration of social workers' reports is apparent: deprivation of the opportunity to test, explain and rebut material used by the tribunal to reach its decision. This seems hardly outweighed by the reasons pointing to a contrary view.

It may be argued that policy requires non-disclosure of the report, since otherwise "the social investigator cannot assure third persons who are interviewed that their information will be treated confidentially." ${ }^{33}$ A privilege ${ }^{34}$ of non-disclosure will operate to conceal informants' identities ${ }^{35}$ and thus increase to some extent the effectiveness of the investigations with consequent benefit to the child. However, in many cases the same protection can be afforded through partial disclosure, such as the use of a summary of the report. ${ }^{36}$ Furthermore, the recognition of a privilege in custody cases would require similar recognition in all other types of litigation where the report might be used, if complete confidentiality is to be assured. Finally, in criminal and security cases, where the dangers incident to informing are greater, the "informer's" privilege

${ }^{30}$ Holmes' Appeal, 379 Pa. 599, 109 A.2d 523 (1954); In re Halamuda, 85 Cal.App.2d 219, 192 P.2d 781 (1948); In re Brown, 201 S.W.2d 844, 849 (Tex. Civ. App., 1947); cf. In re Jones, 41 Wash.2d 764, 252 P.2d 284 (1953). Contra: State ex rel. Palagi v. Freeman, 81 Mont. 132, 262 Pac. 168 (1937); cf. In re Ramsey, 164 Ohio St. 567, 132 N.E.2d 469 (1956); In re Sippy, 97 A.2d 455 (Mun. App. D.C., 1953).

${ }^{31}$ In re Caronna, 197 La. 494, 2 So.2d 1 (1941).

${ }^{32}$ Consult cases cited notes 17 and 23 supra. In People ex rel. Bernat v. Bicek, 405 Ill. 510, 526-27, 91 N.E.2d 588, 596-97 (1950), noted in 18 U. of Chi. L. Rev. 342 (1951), which held unconstitutional a statute authorizing the master in divorce cases to consider welfare agency reports, the Williams case was distinguished.

${ }^{33}$ Gellhorn, Children and Families in the Courts of New York City 331 (1954).

${ }^{34}$ A privilege between social worker and client has been suggested, although nowhere recognized. Morgan and Maguire, Cases and Materials on Evidence 391 (3d ed., 1951). This privilege, however, would seem inapplicable to the typical custody investigation, since the required professional relationship is generally absent.

${ }^{35}$ The text discussion is limited to informants who are not parents. In general, this type of informant may withhold information either by reason of a general reluctance to give information or enter into disputes or because of the fear of possible social or economic reprisals. Parents, however, may be expected to cooperate with the social worker in the hope of obtaining a favorable report or avoiding an unfavorable one. Nevertheless, it may be argued that nondisclosure should be extended to cover parents insofar as notions of privacy are deemed important. Consult discussion note 39 infra.

${ }^{36} \mathrm{This}$ has been done in administrative law where national security is involved. Consult United States v. Nugent, 346 U.S. 1 (1952); Brewer v. United States, 211 F.2d 864 (C.A. 4th, 1954). 
has been rejected when sought to be applied to material used by the tribunal in reaching its decision. ${ }^{37}$

It has also been suggested that disclosure in court of "clinically adverse conclusions... may provoke bitter reactions which will seriously impair the chances either of future agreement between the parties or harmonious compliance with the court's decision." ${ }^{38}$ It would appear, however, that antagonisms raised by recriminative testimony usual in custody litigation could hardly be aggravated by disinterested expert diagnosis. ${ }^{39}$

Another possible argument is suggested by Williams v. New York, where the Court said that when a person's "whole life and characteristics" are in issue, explanation and rebuttal of evidence and cross-examination of witnesses "could endlessly delay criminal administration in a retrial of collateral issues." 40 However, the same type of inquiry in custody cases seems not to have required unduly extended litigation where the social worker was subject to cross-examination on a report made available to the parties for explanation and rebuttal. ${ }^{41}$

${ }^{37}$ Parker v. Lester, 227 F.2d 708 (C.A. 9th, 1955) (administrative denial of seamen's security clearance violates due process when based on information which in order to protect informers' identities was not disclosed). Criminal convictions based on undisclosed informers' information are held invalid under constitutional provisions requiring confrontation of witnesses in criminal cases. Consult 5 Wigmore, Evidence $\$ 1397$ (3d ed., 1940). But the Supreme Court has indicated that such a holding may also be placed on due process grounds. In re Oliver, 333 U.S. 257, 273 (1948). But cf. Stein v. New York, 346 U.S. 156 (1953). Consult generally An Informer's Tale: Its Use in Judicial and Administrative Proceedings, 63 Yale L. J. 206 (1953).

${ }^{38}$ Gellhorn, Children and Families in the Courts of New York City 331 (1954). The Wayne County (Detroit) Friend of the Court suggests that disclosure of the report to the parties "would in many cases undoubtedly raise certain antagonistic issues between the parties, and possibly hinder adjustment of custody and visitation between the litigants and their children." Letter of Frederick C. Hailer, assistant to the Friend of the Court for the Third Judicial Circuit of Michigan, dated Aug. 31, 1956. However, in Wayne County the reports are made available to counsel. Ibid.

${ }^{39} \mathrm{~A}$ related objection to disclosure may be a reluctance to expose intimate feelings and thoughts in open court. The social worker's analysis may go beyond facts known to at least some members of the community, e.g., " $\mathrm{X}$ is a drunkard," and take the form of "X has an Oedipus complex," which would be news to all. However, this objection loses much of its force when it is considered that the same type of evidence may be made public by psychiatrists' testimony.

40337 U.S. 241, 250 (1949).

11 It has been suggested that allowing cross-examination of social workers might take so much time that their work would be crippled. Gellhorn, Children and Families in the Courts of New York City 332 (1954). But this result seems not to have occurred in practice. In Detroit social investigators are allowed to testify and yet the Friend of the Court, which among other duties investigates every divorce case involving minor children and enforces support orders, still seems to be functioning. Letter, op. cit. supra note 38; Squire, Divorce and the Friend of the Court, 29 Mich. S. B. J. 15 (April, 1950); Virtue, Survey of Metropolitan Courts Detroit Area 176 (1950).

It may be suggested that if the often recommended Family Court were created, with an investigative staff and a judge permanently assigned to family cases (consult sources cited in Johnstone, Marital Discord Cases, 31 Ore. L. Rev. 297, 317 at n. 71 [1952]), the time spent in court by social investigators would be at a minimum. An expert judge is less likely to disagree with social workers on what are the relevant factors in a custody case, so that there would be 
Finally, although non-disclosure of social workers' reports may, for the reasons noted above, operate to benefit the child, it does not follow that the welfare of the child necessarily demands the use of secret reports. The possibility of an erroneous or inaccurate report, however unlikely, would, even jas to the child's interests, require some opportunity for correction, best supplied through disclosure of the report to the parties.

Assuming that judicial consideration of undisclosed reports constitutes a denial of procedural due process, the question of what procedural safeguards will overcome "secret evidence" objections remains. Two procedures, cross-examination of the social worker and disclosure of a summary or copy of the report, are possible. It is clear that if only cross-examination is allowed, there is no opportunity to explain and rebut the undisclosed report, although the witness's expert qualifications and methods of investigation may to some extent be tested..$^{42}$ If a summary of the report is also furnished some "secret evidence" objections may yet remain; since the purpose of such partial disclosure is to maintain informants' anonymity, much of the information obtained from interviews would have to be withheld. ${ }^{43}$ However, this procedure may well be acceptable as a proper compromise between the rule against "secret evidence" and the desirability of protecting informants' identities, although falling short of complete disclosure.

There is, however, serious doubt as to whether disclosure of a copy or summary of the social worker's report is possible under existing case-law. Such disclosure may be accomplished in two ways: out of court communication or admission in evidence. The propriety of the former practice seems questionable. If admission in evidence is possible, out of court communication will result in omission from the record on appeal of material which may have had a crucial bearing on the trial court's decision. ${ }^{44}$ And if admission in evidence is not pos-

less reason for counsel to cross-examine the worker to elicit facts not already in the report, considered relevant by lawyers but not by social workers. Consult Gellhorn, Children and Families in the Courts of New York City 310-14 (1954).

42 Consult Jones v. Jones, 23 Wash.2d 657, 665-66, 161 P.2d 890, 894-95 (1945), describing a cross-examination of a social worker on her methods of investigation where counsel had not seen her report.

${ }^{43}$ Consult Parker v. Lester, 227 F.2d 708, 722 (C.A. 9th, 1955).

${ }_{14}$ An off-the-record report or interview held to have been properly considered by the trial court presents an interesting problem in appellate review awards are reviewed by the "substantial evidence" test of actions at law, there is some indication that findings may be affirmed although not supported by substantial evidence on record, if it is presumed that the off-record material supplied the deficiency. See Ruck v. Ruck, Ala. -, 89 So.2d 274 (1956); Nelson v. Nelson, 43 Wash.2d 278, 260 P.2d 886 (1953), both cases affirming without review of evidence where the judge without parties' objection had interviewed the children off the record. Other cases indicate that an off-the-record interview gives additional weight to the findings below. Dougal v. Dougal, - Cal.App.2d - 299 P.2d 404 (1956); Smith v. Smith, 137 Cal.App.2d 512, 290 P.2d 609 (1955); Smith v. Smith, 135 Cal.App.2d 100, 286 P.2d 1009 (1955); Emerson v. Emerson, 117 Colo. 384, 188 P.2d 252 (1947); Trickey v. Trickey, 158 Ohio St. 9, 106 N.E.2d 772 (1952); Prendergast v. Prender- 
sible, out of court communication will violate the policy behind the relevant exclusionary rule of evidence. Thus, it would seem that disclosure should be effectuated through the usual channel-admission in evidence.

When social workers' reports are offered in evidence, several hearsay problems arise. It has been held that the report itself is inadmissible as hearsay, at least when the social worker is not in court. ${ }^{45}$ However, strictly speaking this objection is not removed even if the social worker is in court, for the report remains an out of court statement offered for the truth of the matter asserted.46 Yet it is probable that the opportunity to cross-examine afforded by the social worker's presence will result in the report's admission, assuming that its contents are independently admissible. ${ }^{47}$ And in general, it may be argued that the report itself is admissible under well-recognized exceptions to the hearsay rule. ${ }^{48}$ In fact, it may be doubted whether the report is within the hearsay ban at all. The dangers of faulty perception and narration seem alleviated by the social workers' special skills and training; falsification seems unlikely; and memory is unimportant if the report is more or less contemporaneous. A similar approach is suggested by numerous statutes providing that such reports shall be "competent" or "admissible" as evidence. ${ }^{49}$

gast, 122 S.W.2d 710 (Tex. Civ. App., 1938); Habich v. Habich, 44 Wash.2d 195, 266 P.2d 346 (1954).

With de novo review, to affirm an award supported by the weight of record evidence would seem to require only a presumption that the off-record material does not weigh sufficiently against the findings to offset the record evidence; where the weight of record evidence is against the findings, affirmance would seem to require a presumption that the off-record material offsets the record evidence. The cases, without discussing these presumptions, rely on a rule that a court may not review de novo if the record does not include all the evidence before the trial court. This rule is held to require that without any review of evidence the appellate court must affirm, Rea v. Rea, 195 Ore. 252, 245 P.2d 884 (1952), or reverse, Commonwealth ex rel. Mark v. Mark, 115 Pa.Super. 181, 175 Atl. 289 (1934). Consult generally, 4 Wigmore, Evidence $\$ 1168$ (3d ed., 1940).

45 Dier v. Dier, 141 Neb. 685, 4 N.W.2d 731 (1942).

${ }^{45}$ Grand Forks Building \& Development Co. v. Implement Dealers Mutual Fire Ins. Co., 75 N.D. 618, 31 N.W.2d 495 (1948).

${ }^{47}$ Rohrbaugh v. Rohrbaugh, 136 W.Va. 708, 68 S.E.2d 861 (1951); see Dier v. Dier, 141 Neb. 685, 691, 4 N.W.2d 731,735 (1942). Some courts would add the further requirement that the report be by affidavit. Wilkinson v. Wilkinson, 105 Cal.App.2d 392, 233 P.2d 639 (1951); see Fewel v. Fewel, 23 Cal.2d 431, 436, 144 P.2d 592, 595 (1943).

18 As for example the business records and official written statements exceptions. Or perhaps a new exception. Consult West v. West, 208 S.C. 1, 36 S.E.2d 836 (1943); and statutes cited note 49 infra.

The report itself may also be admissible under the doctrine of past recollection recorded. Its requirements are easily satisfied, since the social worker will probably have forgotten the contents of the report due to the pressure of a busy schedule. Consult generally McCormick, Evidence \$277 (1954).

${ }^{9}$ Cal. Code Civ. Proc. (Deering, 1953) §263; Neb. Rev. Stat. (1952) c. 42, \$307; N.J. Rules of Court (1953) Rule 4:98-8(d), implementing N.J. Rev. Stat. (1952) tit. 2A, c. 168, $\$ 13$.

Admissibility of the report resulting from a social worker's investigation might seem 
Assuming objections to the introduction of the report itself are overcome, its contents must nevertheless be independently admissible. ${ }^{50}$ However, these reports frequently contain information supplied through interviews with schoolteachers, ministers, employers, friends and neighbors. ${ }^{51}$ As such, it is clearly established that the contents of the reports are inadmissible as hearsay, ${ }^{52}$ unless some recognized exception is applicable. ${ }^{53}$ The only intimation to the contrary is in Withrow v. Withrow, where a custody award based on conflicting evidence was remanded for investigation and "report under oath" by a social worker, despite the dissent's warning that such a report would be replete with hearsay. ${ }^{55}$

In support of the Withrow case, which perhaps points to a new hearsay exception for interview material in a social worker's report, several considerations may be urged. Whereas the typical legal inquiry concerns the occurrence of a single past event or series of past events, proper determination of custody cases

authorized by any statute authorizing or requiring such an investigation in custody cases. Nineteen states have such statutes: Arkansas, California, Delaware, Georgia, Indiana, Kentucky, Louisiana, Maine, Massachusetts, Michigan, Montana, Nebraska, New Hampshire, New Jersey, North Carolina, Ohio, Rhode Island, Texas and Virginia. However, where the statute provides for only an investigation it has been held that the written report of such investigation is inadmissible. Dier v. Dier, 141 Neb. 685, 4 N.W.2d 731 (1942) (construing Neb. Comp. Stat. [1929] c. $42, \S 307$, amended in 1945 to obviate this case, Neb. Rev. Stat. [1952] c. 42, \$307); see Brugel v. Hildebrandt, 332 Mich. 475, 52 N.W.2d 190 (1952) (construing Mich. Stat. Ann. [Supp., 1955] c. 25, \$173). The legislative intent might well be that the results of the investigation should be presented to the court through the testimony of the investigator as the court's or a party's witness. On the other hand, statutes providing that the investigator make a report to be "submitted" or "filed with" the court, Ark. Stat. Ann. (Supp., 1955) tit. 22, $\$ \$ 133-36$; Ind. Stat. Ann. (Burns, 1956) tit. 9, c. 28, \$1(b); Ky. Rev. Stat. (Baldwin, Supp., 1956) c. 403, $\$ 90 ;$ Maine Rev. Stat. (1954) c. $166, \$ 69$; N.C. Gen. Stat. (1955) c. 7, \$103(i); R.I. Gen. Laws (1938) c. 496, \$18, and statutes providing that the report be shown to the parties or that the investigator be subject to cross-examination (notes 20-22 supra) would seem to imply that the report itself be admissible in evidence. Jenkins v. Jenkins, 304 Mass. 248, 23 N.E.2d 405 (1939); In re Halamuda, 85 Cal.App.2d 219, 192 P.2d 781 (1948).

${ }^{50}$ Consult Revised Business Entry Statutes: Theory and Practice, 48 Col. L. Rev. 920, 926-32 (1948).

${ }^{51}$ See In re Halamuda, 85 Cal.App.2d 219, 192 P.2d 781 (1948); consult Richmond, Social Diagnosis 164-67 (1917).

${ }^{52}$ Swigart v. Swigart, 115 N.E.2d 871 (Ohio App., 1953); Bestel v. Bestel, 153 Ore. 100, 53 P.2d 525 (1936); see Rohrbaugh v. Rohrbaugh, 136 W.Va. 708, 715, 68 S.E.2d 361, 366 (1951).

${ }^{53}$ As for example admissions, declarations against interest, res gestae and family reputation. 54212 La. 427, 51 So.2d 849 (1947).

${ }^{55}$ Cf. In re Halamuda, 85 Cal.App.2d 219, 192 P.2d 781 (1948), a proceeding to declare a neglected child free of his parent's control, which held admissible hearsay in a probation officer's report of an inquiry required by statute into the "antedecents, character, family history and environment" of juveniles before the court (Cal. Welfare and Institutions Code Ann. [Deering, 1952] \$369): "[I]t is apparent that the inquiry required must be from persons purporting to have knowledge of facts so that the report based on such inquiry must, to a certain extent, be based on hearsay. This seems contemplated by the section." In re Halamuda, supra, at 223 and 783 . This reasoning, if accepted, may be argued to require a similar result in custodv cases. 
requires all relevant information available as to the family situation. The social worker may, through training and experience, be well equipped to know what data should be obtained ${ }^{56}$ and the surest method of obtaining it. ${ }^{57}$ Furthermore, these skills may also afford an effective substitute for cross-examination, at least insofar as they generally include an awareness of the testimonial risks incident to the material supplied by the informants. ${ }^{58}$ The social worker will test and evaluate these risks in a particular interview, and, through a process of comparison with other interviews and selection of the more reliable information, will be able to present a reasonably accurate picture of the total family situation. ${ }^{59}$ Finally, the suggested relaxation of the hearsay rule would operate to alleviate many of the difficulties arising when admission in evidence is refused. The dilemma of choosing between the suppression of concededly valuable evidence and its extra-record consideration would disappear. ${ }^{60}$

Problems comparable to those concerning the use of social workers' reports arise when the judge interviews the child in chambers without the presence of parties or counsel to ascertain his feelings relevant to custody. Such an interview is generally held erroneous ${ }^{61}$ unless counsel, knowing that it has been held,

BB Consult Gellhorn, Children and Families in the Courts of New York City 310-14 (1954), relating a social worker's criticism of a custody case opinion on the grounds of the irrelevancy of the data set out in the opinion.

${ }^{57}$ Much thought has been given in social work circles to interview technique. Consult generally Hamilton, Theory and Practice of Social Case Work 147-92 (2d ed., 1951); Young, Interviewing in Social Work (1935). Interviewing is taught in schools of social work. Cannon and Klein ed., Social Casework c. 9 (1935).

sB Consult Richmond, Social Diagnosis (1917). Chapters 4, 8-12, 14 and 15 discuss the biases and special knowledge of the types of people from whom social workers get their information. Bristol, Handbook on Social Case Recording 37-42, 97-98, 121-22 (1936), instructs students to include in the case record sources of information and probable reliability of informants.

${ }^{59}$ Consult generally Maguire, Heresy about Hearsay, 8 U. of Chi. L. Rev. 621 (1941) (passim). Another consideration may also be urged. Legal examination is generally an attempt to make the witness state what counsel desires to elicit. In sharp contrast is the social worker's technique, aimed instead at eliciting what the informant really feels. Consult generally the authorities cited note 57 supra; compare the suggestion that custody issues arising in divorce and habeas corpus proceedings be referred to the juvenile court "with its independent investigatory arm substituting... unbiased inquiry for litigious procedure." Gilliam and Gilliam, The State as Parens Patriae, 21 Rocky Mt. L. Rev. 375, 383 (1949).

The official written statements exception to the hearsay rule may also afford, either directly or by analogy, support for the view that hearsay in the social worker's report is admissible. It is clear that in some instances at least reports required by statute and hence falling within this exception have been held to effect such a result. McCormick, Evidence $\$ 294$ (1954). In some jurisdictions, social workers' reports are required by statute. Consult statutes cited note 49 supra.

${ }^{60}$ Questions of admissibility are also raised by the use of a summary of the social worker's report as a means of disclosure. The rule requiring an expert to state the basis of his opinions and the rule expressing a preference for concrete factual statements would seem to bar admission, at least as a technical question. Consult generally McCormick, Evidence \$\$11, 14 (1954).

${ }^{61}$ People ex rel. Kessler v. Cotter, 285 App.Div. 206, 136 N.Y.S.2d 515 (1955); Peeples v. Newman, 209 Ga. 53, 70 S.E.2d 749 (1952); Wacker v. Wacker, 279 Ky. 19, 129 S.W.2d 1043 (1939). Contra: Ex parte Leu, 240 Mich. 240, 215 N.W. 384 (1927). 
has-an opportunity to "cross-examine" the child, ${ }^{62}$ or an account of the interview is later given in court. ${ }^{63}$ Examination may well meet "secret evidence" objections, since the examiner will presumably be cognizant of the general subject matter of the interview. A later account in court of the substance of the interview would also seem to alleviate "secret evidence" dangers; moreover, this procedure would probably not be open to admissibility objections, in contrast to the situation of social workers' reports. Provided the judge is considered a competent witness, ${ }^{64}$ his account of the typical interview would be admissible under the state of mind hearsay exception..$^{65}$

Interviews with the child in chambers are held without the parties' presence "to save the child the embarrassment and possible fear of expressing a preference between the mother and father." inconsistent with allowing later examination of the child by counsel, with suitable regulation by the court. Nor would this policy preclude a later account of the interview to the parties for the purposes of explanation and rebuttal. Permanent secrecy is indicated only if it is felt that the future relations of the parents and child may be harmed by disclosing the contents of the interview. In such circumstances, it would therefore seem desirable to use examination of the child as the sole means of overcoming "secret evidence" dangers.

The interview practice is, however, subject to further difficulties. In strange and possibly imposing surroundings the child is asked by the judge to express a preference between parents-a subject on which the child will generally have both complex and shifting feelings. It may thus be desirable to rely in such matters on the expertise of the social worker. The question of whether a statement of preference is necessary in the first instance, the best method of eliciting it and its proper evaluation involve intricate problems of psychology and demand experience, training and skill not often possessed by the judiciary.

62 Hicks v. Hicks, 26 Tenn.App. 641, 655-56, 176 S.W.2d 371, 377 (1943). See Morris v. Morris, 121 Cal.App.2d 707, 709, 264 P.2d 106, 107 (1953); Callen v. Gill, 7 N.J. 312, 319, 81 A.2d 495, 498 (1951); Penn v. Abell, 173 S.W.2d 483, 488 (Tex. Civ. App., 1943); Krieger v. Krieger, 59 Idaho 301, 306, 81 P.2d 1081, 1083 (1938); Daniels v. Daniels, 145 Iowa 422, 124 N.W. 169 (1910).

${ }_{63}$ Morris v. Morris, 121 Cal.App.2d 707, 709, 264 P.2d 106, 107 (1953); Callen v. Gill, 7 N.J. 312, 319-20, 81 A.2d 495, 498-99 (1951). Callen v. Gill contemplates a summary of the interview by the judge in court. In other cases a verbatim transcript was placed on record. Kelly v. Applewhite, 231 S.W.2d 974 (Tex. Civ. App., 1950); Daniels v. Daniels, 145 Iowa 422, 124 N.W. 169 (1910). Neither method literally complies with the rule against "secret evidence," since the judge in the private interview observes the child's demeanor, which cannot be transcribed literally for the record and which may be an important factor in the case of younger, less articulate children.

64 Consult McCormick, Evidence \$68 (1954).

${ }^{65}$ Newburger v. Newburger, 10 Tenn.App. 555, 567 (1930); see Callen v. Gill, 7 N.J. 312, 318, 81 A.2d 495, 497-98 (1951).

${ }^{66}$ Krieger v. Krieger, 59 Idaho 301, 306, 81 P.2d 1081, 1083 (1938). 